\title{
FENOMENA SOSIAL DALAM NOVEL NENEK KARYA RAZALI ENDUN
}

\author{
Social Phenomenan in 'Nenek' by Razali Endun
}

\author{
Rosnani Md Zain \\ nanieyzain@gmail.com \\ Nik Rafidah Nik Muhamad Affendi \\ nikrafidah@gmail.com \\ Universiti Putra Malaysia
}

\begin{abstract}
ABSTRAK
Kertas kerja ini membicarakan fenomena sosial yang terdapat dalam novel Nenek karya Razali Endun. Novel Nenek merupakan pemenang Hadiah Sastera Perdana 2014. Fenomena sosial merupakan kenyataan mengenai masyarakat dan manusia tidak boleh lari daripada membicarakannya. Hal ini kerana, sastera dan masyarakat mempunyai hubungan yang erat. Novel Nenek dikatakan sebuah naskhah yang memaparkan fenomena politik sahaja. Adakah benar dakwaan tersebut. Objektif kajian ini adalah untuk mengklasifikasi dan menganalisis fenomena sosial yang terdapat dalam novel ini. Objektif kajian ini juga adalah untuk menjawab dakwaan sesetengah pihak yang mengatakan bahawa novel Nenek hanya memaparkan fenomena politik sahaja. Hasil kajian mendapati teks ini menyentuh mengenai tatacara perhubungan dalam masyarakat, kekeluargaan, kemiskinan dan pembangunan sosioekonomi masyarakat. Setelah diteliti, fenomena sosial yang terdapat dalam novel Nenek merupakan fenomena semasa. Sehubungan dengan itu, kajian ini melihat fenomena sosial daripada perspektif teori fakta sosial Emile Durkhiem.
\end{abstract}

Kata kunci: sosiologi; novel; Nenek; fenomena sosial; fakta sosial

\begin{abstract}
This article discusses the social phenomenon in a novel entitled Nenek by Razali Endun. Nenek is a winner of Hadiah Sastera Perdana 2014. The social phenomenon is a fact about society and people could not avoid from talking about it since literature and society is closely related. The objective of this study is to classify and analyze the social phenomenon that occurs in Nenek. Another objective is to prove the claims by some people that the novel shows only a political phenomenon. The study found that this novel discusses relations in society, family, poverty and socio-economic development of society. It is found that the social phenomenon in this novel is happened in reality. Accordingly, the study looked at the social phenomenon from the perspective of the theory of social facts by Emile Durkhiem.
\end{abstract}

Keywords: sociology; novel; Nenek; phenomenon social; social facts

\section{PENGENALAN}

Sastera dan masyarakat mempunyai hubungan yang erat. Hal ini kerana sastera merupakan cerita tentang masyarakat. Sastera juga merupakan manifestasi daripada fenomena sosial yang wujud dalam masyarakat. Fenomena sosial yang terjadi dalam masyarakat inilah yang memberi idea kepada pengarang untuk menghasilkan kesusasteraan sama ada dalam bentuk cerpen, drama, novel mahupun puisi. Dalam hal ini, tidak semua yang diperolehi akan diangkat dalam karyanya. Justeru, akan ada penyaringan dan penapisan secara kreatif dan imaginatif terhadap isu atau fenomena-fenomena yang melingkari pemikirannya (Arba'ie Sujud, Nik Rafidah Nik Muhamad Affendi, dan Asiah Abdul Rahman, 2011: 4). 
Karya sastera sebagai fenomena sosial dalam masyarakat tidak hanya dilihat dari segi penghasilan tetapi hakikat penghasilan karya sastera itu sendiri. Secara umumnya, fenomena sosial dapat dijelaskan sebagai kenyataan yang diperhatikan dalam masyarakat yang dapat dikesan melalui tingkah laku masyarakat. Ini bersesuaian dengan pendapat Azemi Salim (1989: 05), fenomeana sosial merupakan peraturan-peraturan mengenai tingkah laku di dalam organisasi merupakan fakta-fakta sosial. Tingkah laku ini merujuk kepada cara bagaimana mereka menyusun untuk mewujudkan sesebuah masyarakat dan bukan hanya sekelompok orang yang kebetulannya tinggal di tempat yang sama di dunia ini. Fenomena sosial yang berlaku dalam masyarakat ini haruslah dijelaskan dengan menghubungkan masyarakat dengan peraturan-peraturan tersebut.

Justeru itu, Zamroni (1992:52) mendefinisikan fenomena sosial sebagai perilaku individu. Fenomena sosial antara lain merangkumi norma-norma, aturan-aturan, adat-istiadat, kebiasaan-kebiasaan sebagai sesuatu yang ada dalam masyarakat dan akan mempengaruhi perilaku masyarakat. Semua itu merupakan sesuatu yang berada di luar individu dan dapat dipelajari tersendiri sebagaimana layaknya kita mempelajari tingkah laku individu. Oleh yang demikian, fakta sosial dapat mempelajari tingkah laku individu dan masyarakat secara keseluruhan. Berdasarkan pendapat tersebut, dapat dijelaskan bahawa fenomena sosial merupakan tingkah laku manusia yang dapat dikenal pasti melalui kefahaman, sebab musabab dan tindakan manusia. Semua ini merupakan faktor yang boleh mempengaruhi pembentukan fenomena sosial dalam sesebuah masyarakat.

Rohana Yusof (1996: 16) pula menyatakan bahawa fenomena sosial dapat dijelaskan sebagai kajian mengenai masyarakat dan tingkah laku manusia. Hassan Shadily (1984: 02), mendefinisikan fenomena sosial sebagai kenyataan mengenai masyarakat yang merangkumi ikatan-ikatan adat, kebiasaan, kepercayaan atau agamanya, tingkah laku serta keseniaannya atau yang disebut kebudayaan yang meliputi segala segi kehidupannya.

Selain itu, ada juga sarjana yang menyatakan bahawa fenomena sosial juga dapat dilihat melalui pendekatan fungsionalisme. Ting Chew Peh (1997: 29), menyatakan bahawa pada umumnya pendekatan fungsionalisme merupakan satu pendekatan yang menganalisis fenomena sosial daripada segi fungsi atau tujuan yang dipenuhinya dalam sesuatu sistem sosial. Fenomena sosial menurut pendekatan fungsionalisme merangkumi sistem ekonomi, sistem politik, sistem komunikasi, sistem nilai dan norma, sistem sosial dan sebagainya. Aspek-aspek tersebut dilihat sebagai fenomena sosial bagi pendekatan fungsionalisme. Pendekatan ini turut memperakuai bahawa fenomena sosial adalah saling berkaitan dan bergantungan. Oleh itu, perubahan dalam satu hal menimbulkan kesan tertentu ke atas yang lain. Tiap-tiap fenomena sosial dianggap mempunyai fungsi bagi memenuhi keperluan atau tujuan tertentu dalam masyarakat.

Berdasarkan pendapat yang telah dinyatakan oleh tokoh-tokoh tersebut mengenai fenomena sosial, maka jelaslah kepada pengkaji bahawa fenomena sosial merupakan fakta atau kenyataan mengenai masyarakat. Kenyataan tersebut lahir daripada tingkah laku manusia yang mencorakkan kehidupan mereka. Fenomena sosial merupakan kenyataan yang lazim berlaku dalam sesuatu kelompok. Adat dan budaya misalnya merupakan fenomena yang dapat diperhatikan dalam masyarakat. Adat dan kebiasaan yang lazim diamalkan oleh sesuatu kelompok telah menjadi budaya hidup mereka. Justeru itu, seseorang yang tidak mengamalkan adat dan budaya tersebut dianggap sebagai melanggar norma-norma hidup yang telah ditetapkan oleh masyarakat. Fenomena sosial merupakan sesuatu yang telah diterima dan dipersetujui bersama oleh masyarakat.

Terdapat beberapa orang pengkaji yang telah melakukan kajian terhadap fenomena sosial dalam karya sastera. Antaranya ialah kajian yang dilakukan oleh Norita Hamdan (1998) telah menyiapkan tulisan ilmiah dengan tajuk Novel Salina Karya A. Samad Said: Dilihat dari Sudut Sosial. Hasil daripada kajian ini, beliau mendapati terdapat pelbagai fenomena sosial yang diketengahkan oleh A.Samad Said dalam novel Salina. Antaranya ialah persoalan mengenai nilai-nilai hidup masyarakat kampung, kesukaran mendapat tempat tinggal, persaingan antara penarik beca, dan kenakalan kanak-kanak. Berdasarkan kajian yang dilakukan oleh Norita ini juga, analisis kajian mendapati bahawa kehidupan masyarakat dalam novel Salina banyak didedahkan dengan kepincangan hidup masyarakat setinggan yang berjuang dalam meneruskan kehidupan. Kehidupan mereka amat daif. Hal ini jelas terbukti melalui watak-watak dalam novel tersebut yang menghadapi pelbagai permasalahan dalam kehidupan mereka selepas peperangan. Fenomena sosial yang dipaparkan oleh A. Samad Said merupakan gambaran kehidupan masyarakat yang benar-benar berlaku ketika itu. Kedaifan dan kesengsaraan hidup juga telah 
memaksa Siti Salina iaitu watak utama sehingga sanggup melacurkan diri bagi meneruskan kehidupan selepas peperangan. Secara keseluruhannya dapat disimpulkan bahawa kajiannya mencakupi pelbagai fenomena sosial yang berlaku dalam masyarakat.

Seterusnya, kajian yang dijalankan oleh Rogayah Ibrahim (2000) yang bertajuk Fenomena Sosial dalam Cerpen-Cerpen Azizi Haji Abdullah. Dalam kajian ini, Rogayah telah menggunakan sebanyak tiga puluh buah cerpen untuk dianalisis. Kajian ini menumpukan kepada fenomena sosial yang berbentuk positif dan fenomena sosial yang berunsur negatif. Hasil kajian mendapati bahawa banyak fenomena sosial yang berunsur negatif sering didedahkan berbanding dengan fenomena sosial yang berunsur positif. Selain itu, Rogayah juga mendapati bahawa Azizi sering memberi pendedahan kepada pembaca mengenai cerita-cerita yang mengetengahkan golongan tua dan mengakhiri cerita-ceritanya dengan kematian watakwatak utama secara tragis. Melalui kajian ini juga, Azizi mampu menggarapkan fenomena sosial melalui karya-karyanya supaya pembaca dapat berfikir bahawa karya sastera bukan sekadar berfungsi untuk memberi hiburan malah mengandungi pengajaran daripada peristiwa yang berlaku dalam kehidupan seharian.

Selain itu, kajian mengenai fenomena sosial mendapat perhatian daripada Nik Rafidah Nik Muhamad Affendi (2011). Kajian beliau bertajuk Novel Remaja Jibam: Kajian Fenomena Sosial. Kajian yang dihasilkan ini bertujuan mengkaji fenomena sosial yang diketengahkan oleh pengarang sehingga menjadi perhatian kepada golongan remaja. Hasil kajian menunjukkan bahawa fenomena sosial yang terdapat dalam novel Jibam merupakan fenomena yang berlaku dalam persekitaran mereka. Kajian ini hanya memfokuskan kepada aspek kemanusiaan, sosioekonomi dan kekeluargaan. Pendekataan psikologi Sigmud Freud dan Teori Kekecewaan-Keagresifan dan Teori Tingkah Laku Colson diaplikasikan dalam kajian ini bagi menghuraikan fenomena sosial yang terdapat dalam novel Jibam.

Selanjutnya, Nik Rafidah Nik Muhamad Affendi bersama-sama Arba'ie Sujud dan Liliy Salwani Razali (2012) telah melakukan kajian mengenai Fenomena Sosial dalam Cerita Rakyat Kanak-Kanak. Kajian yang dijalankan ini memberi tumpuan kepada fenomena sosial seperti nilai kemanusiaan masyarakat tradisional, sistem kepercayaan masyarakat tradisional dan juga tentang sistem pemerintahan masyarakat tradisional. Hasil kajian mendapati bahawa terdapat pelbagai amanat dan juga pedoman dari masyarakat kepada masyarakat yang diungkapkan dalam bentuk cerita. Kajian juga mendapati banyak unsur-unsur positif dan negatif dipaparkan dalam cerita rakyat yang boleh dijadikan panduan dan sebagai sumber rujukan kepada kanak-kanak pembaca. Antara nilai yang terkandung melalui fenomena sosial dalam cerita rakyat adalah nilai berbudi, pengetahuan tentang adat, prinsip undang-undang, perbuatan baik dibalas dengan kebaikan dan sebaliknya. Kajian ini jelas membuktikan bahawa penceritaan cerita rakyat secara tidak langsung dapat membawakan pelbagai bentuk fenomena sosial yang berguna kepada pembaca, terutamanya kepada kanak-kanak.

Di samping itu terdapat juga kajian yang dilakukan oleh Herni Binti Syam (2015) yang bertajuk Fenomena Sosial dalam Kumpulan Cerpen Tasik Syahdu Karya A. Samad Said dari Bacelor Sastera, Universiti Putra Malaysia. Dalam kajian ini, Herni telah menggunakan teori Sosiologi Sastera sebagai pendekatan kajian. Melalui kajian ini juga, Herni mendapati bahawa terdapat lapan jenis fenomena sosial yang berkisar dalam cerpen tersebut. Antaranya ialah tatacara perhubungan dalam masyarakat, pendidikan, keagamaan, perpaduan dalam masyarakat, masalah sosial, peperangan, kemiskinan, dan pengangguran. Oleh itu, fenomena sosial yang dipaparkan ini jelas membuktikan bahawa karya A. Samad Said bukan sekadar mabuk dengan kata-kata tetapi ada mesej yang ingin disampaikan.

Shamini A/P Paramasivam (2015) turut menjadikan fenomena sosial sebagai bahan kajiannya. Shamini telah menyiapkan latihan ilmiah dengan tajuk Cerpen-Cerpen Pilihan Azizi Haji Abdullah Dilihat Daripada Perspektif Sosiologi. Kajian ini bertujuan untuk melihat fenomena sosial yang terdapat dalam beberapa cerpen Azizi iaitu cerpen Bapa, Tulang Pekasam Ikan Puyu, Wau Kepala Burung, Latifah Rabbaniah, Seladang, Kecundang Seorang Petani, Tiruselvam, Keakuan, Menuju ke Takah Tujuh, Kipas Angin, Anak, Bibit Cinta, Kita Kahwin Darling, Aku Anak Tanjung, Kehidupan di Tepi Rel dan Pelarian Yang Kedua. Hasil kajian mendapati bahawa ternyata jelas terdapat fenomena sosial dalam cerpen-cerpen Azizi. Antara fenomena sosial yang didapati dalam kajian tersebut adalah soal hubungan kekeluargaan, permasalahan masyarakat, hubungan dalam masyarakat, kemiskinan dan pendidikan. Secara keseluruhannya Azizi berjaya memaparkan fenomena sosial yang terdapat dalam cerpen-cerpen yang dikaji. 
Berdasarkan kajian-kajian lepas, walaupun terdapat banyak pengkaji yang telah melakukan kajian terhadap fenomena sosial namun pengkaji lebih berminat menggunakan karya-karya Azizi Haji Abdullah sebagai bahan kajian. Bukan itu sahaja, terdapat juga pengkaji yang menjadikan cerita rakyat dan novel remaja dalam menjelaskan mengenai fenomena sosial. Setakat kajian ini dilakukan, pengkaji belum menemui kajian mengenai fenomena sosial yang menggunakan novel Nenek sebagai bahan kajian. Oleh itu, kajian ini akan memfokuskan fenomena sosial yang terdapat dalam novel Nenek karya Razali Endun.

\section{PENYATAAN MASALAH}

Kajian ini bermula apabila timbul dakwaan sesetengah pihak yang tidak berpuas hati dengan kemenangan Razali Endun menerusi novel Nenek yang memenangi Hadiah Sastera Perdana 2014 yang didakwa sebuah novel yang sarat dengan fenomena politik sahaja.

Ini dapat dilihat menerusi kenyataan yang dikeluarkan oleh Awang Azman Awang Pawi (Dewan Sastera, 2016) menegaskan bahawa belum pernah ada novel tempatan yang seberani Nenek memaparkan isu politik kepartian.

Berdasarkan penelitian pengkaji, ada juga pihak yang menolak dakwaan tersebut. Antaranya ialah Disman (Dewan Sastera, 2016) yang menyatakan bahawa walaupun novel Nenek diluar dugaan namun beliau mengakui novel tersebut antara novel penting yang dilahirkan beberapa tahun kebelakangan ini. Beliau menambah, Nenek merupakan sebuah novel yang menyorot hal kemanusiaan yang tidak kira apa jua bangsa. Malah, beliau turut mengakui bahawa Nenek merupakan novel terbaik karya Razali Endun setakat ini walaupun ia tidak kompleks seperti Salina dan Saudagar Besar dari Kuala Lumpur. Hal ini kerana fenomena sosial yang diketengahkan oleh Razali Endun amat dekat dengan masyarakat dan isu tersebut merupakan masalah yang melanda masyarakat pada kebelakangan ini.

Latifah Arifin dalam Berita Harian keluaran 10 Februari 2016 turut menyokong pendapat tersebut dengan mengatakan bahawa Nenek merupakan sebuah naskhah yang memenuhi kriteria novel untuk Melayu yang membawa gagasan penting, iaitu keutuhan bangsa bergantung kepada ciri masyarakatnya dengan mengamalkan hidup harmoni, menjaga warisan budaya dan memelihara tanah air daripada dijual beli sewenangnya.

Perkara tersebut juga disokong oleh Ahli Panel Penilai HSPM yang menegaskan bahawa Razali Endun berjaya meneroka permasalahan politik, ekonomi dan sosial dengan bahasa yang sederhana serta gaya penceritaan yang realistik. Fenomena sosial yang diketengahkan ini ternyata begitu realistik dan sememangnya fenomena ini wujud dalam masyarakat. Gambaran masyarakat yang diketengahkan oleh Razali Endun dalam novel Nenek ini begitu menyentuh hati kerana kesengsaraan yang terpaksa dilalui oleh penduduk kampung kerana penindasan daripada golongan kapitalis. Golongan ini hanya memikirkan keuntungan semata-mata tanpa mempedulikan derita rakyat tertindas akibat pengambilan tanah mereka untuk pembangunan.

Percanggahan pendapat antara ahli akademik, penulis novel dan pengkritik sastera mendorong pengkaji untuk membuat kajian lanjut dengan mengklasfikasikan dan menganalisis fenomena sosial yang terdapat dalam novel Nenek. Bukan itu sahaja, dalam kajian ini juga akan menjawab persoalan adakah benar bahawa novel Nenek hanya sarat dengan fenomena politik sahaja seperti yang didakwa oleh sesetengah pihak. Justeru itu, dalam memperkatakan mengenai fenomena sosial yang diketengahkan oleh Razali Endun dalam novel Nenek, pengkaji akan menggunakan teori fakta sosial.

\section{OBJEKTIF KAJIAN}

1. Mengklasifikasikan fenomena sosial yang terdapat dalam novel Nenek.

2. Menganalisis fenomena sosial yang terdapat dalam novel Nenek dengan menggunakan teori fakta sosial.

3. Menjelaskan dakwaan yang mengatakan bahawa novel Nenek hanya sarat dengan fenomena politik sahaja. 


\section{METODOLOGI}

Dalam analisis ini pengkaji telah menggunakan kaedah kualitatif pada keseluruhan kajian. Selain itu, pengkaji telah menggunakan pendekatan kajian iaitu kaedah analisis kandungan. Kaedah ini dipilih kerana pengumpulan data dan analisis data bersumberkan kandungan teks, iaitu novel Nenek. Oleh sebab kajian ini memberikan tumpuan khusus kepada analisis terhadap novel Nenek, maka kaedah ini memberi kelebihan kepada pengkaji lebih dekat dengan teks yang akan dianalisis.

Di samping itu, pengkaji akan menggunakan teori fakta sosial yang diasaskan oleh Emile Durkheim. Fakta sosial menjadi idea utama Durkheim dalam penyelidikan sosiologi. Fakta sosial juga dianggap sebagai benda (things) yang berbeza dengan pemikiran. Prinsip yang diperkenalkan ialah kita perlu mengkaji fakta sosial sama seperti mana kita mengkaji benda. Ini bermaksud kehidupan sosial dapat dikaji seperti objek yang nyata (Amir Hassan Dawi, 1999: 15). Dalam buku The Rules of Sociological Methods (1985: 13), Durhkeim mengatakan fakta sosial sebagai:

\section{"A social facts is very way of acting, fixed or not, capable of exercising on the individual an external constraint, or again, every way of acting which is general throught a given society, while at the same time existing in its own right independent of its individual manifestations".}

Oleh itu, fakta sosial ini dapat difahami sebagai cara bertindak, berfikir, dan merasa yang ada diluar individu dan sifatnya memaksa serta terbentuk kerana adanya pola di dalam masyarakat. Ertinya, sejak manusia dilahirkan secara tidak langsung ia diharuskan untuk bertindak sesuai dengan lingkungan sosial dimana ia dididik dan sangat sukar baginya untuk melepaskan diri dari aturan tersebut. Sehingga ketika seseorang berbuat lain dari apa yang diharapkan oleh masyarakat maka ia akan mendapatkan tindakan koreksi, ejekan, celaan, bahkan akan dihukum. Sehubungan dengan itu, Durkheim telah menggariskan tiga sifat utama fakta sosial iaitu bersifat objektif, tidak bersifat individual, dan bersifat sosiologi.

Prinsip pertama yang dikemukakan oleh Durkheim mengenai teori fakta sosial ialah tidak bersifat individual. Fakta sosial itu bersifat umum atau tersebar secara meluas dalam suatu masyarakat. Justeru itu, fakta sosial ini merupakan milik bersama bukan bersifat perseorangan. Ini bermakna seperti yang telah dinyatakan oleh Durkheim, peningkatan kadar bunuh diri bukan disebabkan oleh faktor dalaman individu tetapi masyarakat juga harus disalahkan. Kadar bunuh diri meningkat kerana seseorang tidak dapat mengikut peraturan yang telah ditetapkan oleh anggota masyarakat. Contoh yang lain pula ialah kadar kemiskinan dalam sesebuah kampung tidak boleh dianggap sebagai fakta sosial sekiranya hanya terdapat sebuah keluarga sahaja yang berada dalam kemiskinan. Ini bermakna fakta sosial merupakan masalah masyarakat bukannya masalah individu.

Teori ini juga bersifat objektif. Metod ini didominasi oleh gagasan bahawa fakta sosial merupakan hal-hal dan harus ditangani demikian. Fakta ini memiliki kekuatan untuk menekan dan memaksa individu menerima dan melaksanakannya. Dalam fakta sosial sangat jelas sekali bahawa individu itu dipaksa, dibimbing, diyakinkan, didorong dengan cara tertentu yang dipengaruhi oleh berbagai jenis fakta sosial dalam lingkungan sosialnya. Hal ini bermakna, fakta sosial mempunyai kekuatan untuk memaksa individu untuk menerima segala jenis peraturan yang telah ditetapkan dalam masyarakat. Jika dilihat dari prinsip Durhkeim ini, kita mungkin dapat mengatakan bahawa norma sosial sebagai sesuatu di luar individu, membatasi, dan mengawal tingkah laku mereka. Sekiranya individu tidak mengalami tekanan atau berasa dipaksa, dia sebenarnya telah menghayati atau telah sebati dengan norma masyarakatnya dan sudah menerima norma itu sebagai piawai bagi tingkah lakunya sendiri (Rahimah Abdul Aziz, 1993: 36). Misalnya, adat dan kebiasaan yang telah ditetapkan dalam masyarakat dan mesti dipatuhi oleh seseorang individu walaupun pada hakikatnya mereka tidak dapat menerima aturan yang telah ditetapkan. Jika melanggar aturan tersebut, mereka akan dipandang serong oleh masyarakat.

Teori fakta sosial secara eksklusif bersifat sosiologi. Fakta sosial harus dijelaskan berdasarkan fakta-fakta sosial yang mendahuluinya sehingga dapat mengetahui mengapa wujudnya fakta sosial tersebut. Setelah menemui sebab terjadinya fakta sosial tersebut, seterusnya mencari penyebab fakta sosial tersebut masih ada. Suatu fakta sosial hanya dapat dijelaskan oleh fakta sosial lainnya, hal mana dimungkinkan dengan cara menonjolkan faktor pokok dalam evolusi kolektif pada lingkungan sosial dalaman. Penjelasan mengenai fakta sosial yang masih wujud dapat dijelaskan melalui fungsi kewujudan 
tersebut. Misalnya, kanak-kanak telah diajar dan dididik untuk makan, minum dan tidur secara teratur. Ini menunjukkan bahawa aturan tersebut telah wujud sebelum kanak-kanak dilahirkan. Peraturan dan perilaku tersebut juga merupakan sesuatu yang normal dalam masyarakat.

Kesimpulannya terdapat tiga prinsip yang akan digunapakai dalam kajian ini, iaitu bersifat objektif, tidak bersiftat individual dan bersifat sosiologi.

\section{PERBINCANGAN KAJIAN}

Pada bahagian analisis pengkaji akan memperlihatkan beberapa elemen fenomena sosial yang terdapat dalam novel Nenek karya Razali Endun. Antaranya ialah:

i. Tatacara perhubungan dalam masyarakat.

ii. Kekeluargaan

iii. Kemiskinan

iv. Pembangunan sosioekomi masyarakat

\section{Tatacara Perhubungan dalam Masyarakat}

Tatacara perhubungan dalam masyarakat merujuk kepada kaedah atau cara yang digunakan oleh masyarakat dalam menguruskan kehidupan bersama. Hal ini amat penting bagi mewujudkan hubungan yang harmoni dalam satu komuniti. Oleh yang demikian, pengkaji akan memperlihatkan perhubungan dalam masyarakat yang menyentuh aspek adab berjiran, adab melayan tetamu dan budaya gotong-royong.

Dalam novel Nenek karya Razali Endun, tatacara perhubungan dalam masyarakat dapat dilihat melalui perhubungan yang positif antara kaum. Hal ini dapat dilihat melalui semangat kejiranan yang masih diamalkan memberi gambaran kepada kita bahawa rakyat Malaysia masih mengekalkan perhubungan yang positif bagi mewujudkan keharmonian dalam masyarakat. Ditinjau dari sudut Islam, jiran merujuk kepada orang yang ada hubungan dengan anda dalam sesuatu kawasan, tempat tinggal berdekatan, iaitu bilangan rumah-rumah sebanyak 40 buah rumah daripada penjuru timur, barat, utara dan selatan di sekeliling rumah anda (Yahaya Ibrahim, 1995: 63). Ini dapat dilihat melalui gambaran watak Mak Som yang mengambil berat akan jirannya, iaitu How. How menyara keluarganya di atas tanah sewa Mak Som dengan menanam sayur-sayuran. Mak Som bimbang pengambilan tanah tersebut akan menjejaskan ekonomi keluarga How. Hal ini kerana How tidak memiliki tanah sendiri. Dia hanya bergantung kepada tanah penduduk kampung. Walaupun berlainan bangsa, tetapi Mak Som begitu prihatin terhadap nasib yang menimpa How.

Namun, dia kemudian sedar bahawa kalau tanah itu diambil, How juga akan terjejas. Di mana pula dia akan bercucuk tanam sayur-sayurannya. How juga akan mengalami kerugian. Kalau tanah sawah itu diambil Syarikat Padu Menang, tuan tanah sekurang-kurangnya mendapat pampasan. Namun, How mendapat apa? Putih mata sahaja. Kalau hal itu berlaku, tentu dia mengalami kerugian. Mahu tidak mahu, terpaksa pula How berpindah mencari tempat baharu.

(Nenek, hlm: 80)

Semangat kejiranan yang ditonjolkan oleh Mak Som ini bersesuaian dengan pendapat yang dinyatakan oleh Mustafa Daud iaitu:

'Dalam masyarakat mana sekalipun amalan berjiran adalah satu norma dan fenomena sejagat. Malah
perpaduan sesuatu masyarakat itu dapat diukur melalui tinggi rendahnya mutu hidup amalan berjiran.
Ertinya semakin erat dan tinggilah prestasi perpaduan masyarakat tersebut dan sebaliknya'.

(Mustafa Daud, 1999: 52)

Selain daripada adab berjiran, Razali Endun dalam novel Nenek juga menerapkan budaya gotongroyong yang masih diamalkan oleh penduduk di Kampung Bertam Malim. Budaya gotong-royong ini amatlah penting bagi menguatkan ikatan persaudaraan dan perpaduan antara anggota masyarakat. Selain daripada itu, budaya gotong-royong akan menjadikan sesuatu pekerjaan dapat diselesaikan dengan cepat. Contohnya, budaya gotong-royong ini dilakukan apabila tiba musim menuai padi. Tidak kira lelaki atau 
perempuan, masyarakat akan bekerjasama dalam menjalankan aktiviti tersebut. Ini dapat dilihat berdasarkan petikan di bawah:

\begin{abstract}
'Dulu kalau musim turun ke sawah, orang kampung buat gotong-royong. Bukan saja orang lelaki, anak dara pun turut serta", ujar Mak Som sambil meneruskan langkahnya satu demi satu di atas permatang.
\end{abstract}

(Nenek, hlm: 64)

Sehubungan dengan itu, Wan Rafaie (1993) dalam Abdul Halim Othman (1993: 112) mengatakan bahawa masyarakat Melayu banyak menekankan kerjasama, tolong-menolong, perpaduan dan lain-lain yang menjadi ciri gotong-royong. Gambaran ini sangat benar pada masa dahulu kerana kekurangan teknologi dan memerlukan tenaga kerja yang ramai untuk mengusahakan sesuatu kerja dalam masa yang singkat. Aktiviti gotong-royong ini banyak berlaku dalam masyarakat tani. Justeru penerapan aktiviti sedemikian seperti yang ditonjolkan oleh Razali Endun dalam novel Nenek untuk memberi kesedaran kepada masyarakat hari ini bahawa budaya tersebut amat penting dan perlu diteruskan oleh generasi pada masa akan datang.

Seterusnya dalam novel Nenek karya Razali Endun memperlihatkan tatacara perhubungan dalam masyarakat melalui budaya masyarakat yang masih lagi menghormati tetamu. Dalam hal ini Islam amat menggalakkan umatnya melayan baik tetamu yang berkunjung ke rumah mereka. Menghormati tetamu dan memuliakannya adalah di antara sifat terpuji yang disyariatkan dalam Islam. Bahkan dalam Islam kemuliaan tetamu ini diperlihatkan melalui kisah di zaman Rasulullah, bagaimana Allah mencintai salah seorang sahabat yang telah menghormati tetamu Rasulullah dengan mengenepikan kepentingan diri dan keluarga semata-mata untuk menghormati dan memuliakannya yang dinyatakan oleh Abdul Aziz Ismail (1999) dalam Johari Alias (1997: 99). Contohnya dapat dilihat melalui perwatakan yang ditonjolkan oleh pembantu rumah Dato' Mahfus yang melayan baik tetamu Dato' Mahfus. Beliau telah menyediakan air oren dan cucur badak kepada tetamu Dato' Mahfus. Keadaan ini dapat dilihat melalui petikan di bawah:

Sejurus kemudian, pembantu rumah Dato' Mahfus, Mariati tiba menatang jag air oren dan sepiring kuih cucur badak yang baru digoreng pagi itu. Memang begitulah kebiasaan Mariati. Jika ada tetamu di rumah Dato’ Mahfus, dia akan segera menyediakan hidangan untuk mereka.

(Nenek, hlm: 162)

Elemen-elemen tatacara perhubungan dalam masyarakat seperti yang telah dinyatakan sangat penting untuk diteruskan oleh generasi akan datang. Justeru dalam hal ini Durkheim (1983: 143) ada mengatakan bahawa individu dalam masyarakat perlu dibimbing, diyakinkan dan didorong dengan cara tertentu yang dipengaruhi oleh fakta sosial dalam lingkungan sosialnya. Hal ini bertujuan untuk melahirkan masyarakat yang berdisiplin seterusnya mewujudkan perhubungan yang harmoni dalam masyarakat.

\title{
Kekeluargaan
}

Menurut Fatimah Abdullah (2015: 17), keluarga selalu dirujuk sebagai satu kelompok sosial yang dicirikan oleh tempat tinggal yang sama, adanya kerjasama ekonomi, melaksanakan fungsi reproduksi di samping mendidik anak-anak. Sebuah keluarga biasanya terdiri daripada pasangan suami isteri berserta dengan seorang atau beberapa orang anak mereka, termasuk juga anak angkat.

Rozumah Baharudin dan Rumaya Juhari (2002: 04) melihat daripada perspektif Islam, keluarga adalah struktur istimewa di mana ahli mempunyai hubungan darah atau hubungan perkahwinan; hubungan ini merangkumi elemen saling mengharap seperti yang digariskan dalam agama, undangundang dan dihayati oleh setiap ahlinya.

Manakala Burges dan Locke (1953) dalam Rozumah Baharudin dan Rumaya Juhari (2002: 04) mendefinisikan keluarga sebagai sekumpulan orang yang mempunyai hubungan darah atau diangkat, mendiami satu isi rumah, berinteraksi dan berkomunikasi antara satu sama lain menerusi peranan masingmasing sebagai suami isteri, ibu-anak, anak lelaki-anak perempuan, adik-beradik mereka cipta dan mengekalkan budaya yang sama. 
Dalam konteks kajian ini, pengkaji akan melihat hubungan kekeluargaan yang positif. Antara aspek kekeluargaan yang akan dibincangkan ialah hubungan antara anak dengan ibu dan hubungan suami isteri.

Fenomena kekeluargaan ini dapat dilihat melalui perhubungan positif antara ibu dengan anak. Dato' Mahfus amat menghormati ibunya Mak Som. Walaupun sentiasa berlainan pendapat. Mahfus telah berjanji pada dirinya akan sentiasa menghormati Mak Som walaupun sekarang dia sudah berpangkat Dato'. Baginya, Mak Som adalah segala-galanya. Dalam situasi yang lain juga, Mahfus tidak pernah melawan cakap ibunya walaupun kadang-kadang kata-kata yang dipertuturkan oleh Mak Som menguris hatinya. Bukan itu sahaja, Mak Som dan Mahfus juga sering bertelagah mengenai penggunaan tikar mengkuang. Bagi Mahfus penggunaan tikar mengkuang tidak lagi relevan pada zaman ini. Namun, Mak Som tetap dengan pendiriannya untuk mempertahankan warisan bangsa. Walaupun begitu, Mahfus tetap menghormati keputusan ibunya dan tidak melawan. Hal ini bersesuaian dengan ajaran Islam yang menyuruh umatnya menghormati ibu bapa. Fenomena tersebut dapat diperhatikan dalam petikan di bawah:

Walaupun demikian, Dato'Mahfus berazam untuk tidak pernah lupakan atau berlagak sombong di depan Mak Som. Baginya Mak Som adalah segala-galanya meskipun kadangkala ibunya itu tidak sehaluan dengan fikirannya. Sebenarnya, Dato' Mahfus bukan sentiasa tidak bersetuju dengan Mak Som, tetapi keadaan semasa seolah-olah memerangkap.

(Nenek, hlm:78)

Islam amat mementingkan adab kepada ibu bapa. Adab dan cara kita menghadap mereka mesti lebih istimewa daripada menghadap orang-orang lainnya. Si anak, sama ada lelaki atau wanita, wajib kepadanya bercakap secara lembut, sopan dan kasih sayang kepada ibu bapanya. Si anak tidak boleh bercakap kasar dan mengatakan kata-kata yang tidak baik sekalipun ibu bapanya terkadang memulakan kata-kata kuat dan kasar (Abdullah Ghalib, 2003: 87).

Tanggungjawab seorang anak bukan sahaja mentaati segala perintah ibu bapa. Malah lebih besar lagi. Salah satu tanggungjawab seorang anak terhadap ibunya ialah menjaga dan merawat ibu ketika sakit. Kesanggupan Siti Sakinah menjaga ibunya yang sedang sakit mengembirakan hati ibunya. Siti Sakinah merupakan anak bongsu Mak Som. Walaupun tinggal berjauhan dengan Mak Som, tetapi dia sanggup menjaga ibunya yang sedang sakit. Mak Som merasakan sentuhan anaknya, Sakinah mampu mengurangkan kesakitan yang dialami. Fenomena tersebut dapat dibuktikan melalui petikan di bawah:

Di rumah Mak Som banyak dibantu Siti Sakinah. Tanpa tongkat, Mak Som memang memerlukan bantuan tangan anak bongsunya. Bagi Mak Som, pegangan anaknya itu bagaikan suatu mukjizat yang mampu mengurangkan kesakitan dideritainya.

(Nenek, hlm: 87-88)

Situasi yang dialami oleh Mak Som ini dapat dijelaskan melalui pendapat yang dinyatakan oleh Wan Abdul Halim Othman (1993: 90-91) apabila seseorang sudah tua dan uzur, anak perempuan akan sentiasa menjaganya...Anak lelaki hanya menjenguk sambil berkata, Ah, Ayah sakit!' dan selepas itu pergi. Tetapi anak perempuan akan menjaga, menyediakan minuman dan sebagainya. Jadi, apabila saya memikirkan hari tua, saya mahu seorang anak perempuan'”. Seperti yang telah dinyatakan oleh Wan Abdul Halim menunjukkan kepada kita bahawa anak perempuan lebih bertanggungjawab dalam menjaga ibu yang sedang sakit berbanding dengan anak lelaki.

Perhubungan suami dan isteri juga penting dalam menjaga keharmonian rumahtangga. Peranan isteri dalam perkahwinan adalah amat penting. Ini merupakan faktor penentu terhadap kejayaan perkahwinan tersebut (Hussin Salamon dan Mohd. Nasir Ripin, 1997: 86). Salah satu tanggungjawab seorang isteri ialah menyenangkan hati suami dengan mengambil berat akan keadaan mereka. Sikap prihatin tersebut ditonjolkan oleh Halimah. Berikutan sikap pelik Mahfus yang pulang dari pejabat, telah menimbulkan tanda-tanya kepada Halimah. Namun, Mahfus hanya mendiamkan diri. Fenomena tersebut dapat dilihat dalam petikan di bawah:

Setibanya di rumah, Mahfus terus masuk ke biliknya. Sejurus kemudian isterinya, Halimah mengekori dengan perasaan pelik. Halimah cuba bertanyakan kalau ada sebarang masalah menimpa di pejabat, 
namun Mahfus sekadar mendiamkan diri. Mahfus nampaknya tidak berminat untuk berkata-kata ketika itu. Sebentar kemudian, Halimah keluar semula dengan wajah muram.

(Nenek, hlm: 23)

Sehubungan dengan itu, Hussin Salamon dan Mohd. Nasir Ripin (1997: 87) mengatakan bahawa seorang isteri seharusnya tidak mengenepikan keperluan suami atau tidak menghiraukan permintaannya. Semakin banyak seorang isteri mengambil berat tentang suaminya, semakin bertambah kasih sayang suami kepadanya. Kebanyakan suami yakin bahawa sifat mengambil berat isteri kepada mereka merupakan luahan kasih sayang mereka kepada suami.

Selain itu, sikap suami yang bertanggungjawab akan melahirkan sebuah institusi keluarga yang bahagia. Sikap tanggungjawab Mahfus telah mendorong beliau meringankan beban isterinya dengan menggaji seorang pembantu rumah ekoran daripada kawasan rumah mereka terlalu luas. Lagipun dari segi ekonomi, Mahfus mampu. Fenomena tersebut dapat diperhatikan dalam petikan di bawah:

Oleh sebab kawasan rumah mereka agak luas, Dato' Mahfus berjanji kepada isterinya untuk menggaji seorang pembantu rumah. Ia bukan masalah lagi kerana Dato' Mahfus memang sudah ada kemampuan sekarang. Elaun sebagai ahli lembaga pengarah Syarikat Padu Menang Sdn. Bhd., serta perolehan daripada perniagaan syarikatnya sendiri lebih daripada mencukupi untuknya menggaji seorang pembantu rumah.

(Nenek, hlm: 56)

Seorang suami yang bertanggungjawab dapat menjadikan hubungan yang baik dalam kehidupan berumahtangga. Sikap tanggungjawab yang ditonjolkan oleh pengarang ini juga akan menyebabkan hubungan suami isteri itu berkekalan. Hal ini sama seperti yang di katakan oleh Abd Rahim Abd Rashid:

'Nilai bertanggungjawab dalam keluarga penting sebagai asas untuk memelihara dan mempertahankan institusi sosial yang penting kepada masyarakat'’.

(Abd Rahim Abd Rashid, 2001: 104)

Elemen-elemen tatacara perhubungan dalam masyarakat seperti yang telah dinyatakan sangat penting untuk diteruskan oleh generasi akan datang. Justeru dalam hal ini Durkheim (1983: 143) ada mengatakan bahawa individu dalam masyarakat perlu dibimbing, diyakinkan dan didorong dengan cara tertentu yang dipengaruhi oleh fakta sosial dalam lingkungan sosialnya. Hal ini bertujuan untuk melahirkan sebuah institusi keluarga yang harmoni.

\section{Kemiskinan}

Kemiskinan merupakan masalah yang telah lama membelenggu masyarakat kita. Walaupun negara kita boleh dianggap sebagai negara yang sedang membangun, namun pada hakikatnya masih ramai rakyat Malaysia yang berada dalam paras kemiskinan terutamanya di luar bandar. Menurut Norazit Selat (1993: 71) kemiskinan merupakan suatu konsep yang relatif. Taraf hidup seseorang dikatakan rendah atau miskin apabila dibandingkan dengan taraf hidup orang lain. Islam tidak memandang suci kepada kemisikinan, malah memandangnya sebagai penyakit yang merbahaya (Haron Din, 2007: 90). Justeru itu, Rasulullah saw pernah bersabda "kemiskinan boleh membawa kepada kekufuran". Oleh yang demikian, kemiskinan perlu dihapuskan. Menurut, Mahmood Zuhdi Ab. Majid (1999) dalam Haron Din (2007: 07), baginda Rasulullah SAW pernah menegaskan kalaulah kemiskinan itu diibaratkan sebagai manusia, sudah tentu baginda akan membunuhnya.

Sehubungan dengan itu, isu kemiskinan haruslah ditangani agar kita tidak tergolong menjadi manusia yang kufur. Dalam menangani masalah kemisikinan, punca dan sebab haruslah diketahui terlebih dahulu. Oleh itu, dalam konteks kajian ini, pengkaji akan memperlihatkan fenomena kemiskinan yang terdapat dalam novel Nenek karya Razali Endun. Isu kemiskinan ini dikaitkan dengan pembangunan yang tidak terancang.

Dalam novel Nenek (2014) karya Razali Endun, fenomena kemiskinan berlaku kerana daya pengeluaran padi yang rendah dalam kalangan petani. Hal ini kerana, pembinaan kawasan perumahan di kampung tersebut telah menyebabkan bekalan air tidak dapat disalurkan ke kawasan sawah. Oleh yang 
demikian, penduduk-penduduk kampung tidak dapat mengusahakan tanaman padi. Fenomena tersebut dapat dilihat melalui petikan berikut:

Tanah sawah itu sudah tidak dikerjakan lagi oleh orang kampung semenjak taman perumahan dibina di lereng dan di atas bukit di kampung itu. Pembangunan projek perumahan itu menyebabkan bekalan air tidak masuk ke situ. Lama-kelamaan paras sawah menjadi lebih tinggi berbanding tali air menyebabkan bekalan tidak dapat masuk ke situ. Sawah menjadi kontang dan mula terbiar begitu sahaja sedikit demi sedikit tanpa diusahakan. Masalah itu berlaku kira-kira 17 tahun lalu. Ketika itu Haji Kiran masih hidup. Keadaan tidak memberangsangkan itu memudaratkan minat penduduk kampong untuk terus mengusahakan sawah. Haji Kiran dan Mak Som juga begitu. Patah semangat melihat tanah sawah yang kontang itu.

(Nenek, hlm: 05)

Justeru itu, menurut Abd. Malik (1996) dalam Norzalinda Mohd Ali Hanafiah (2006:118) mengatakan bahawa jumlah pengeluaran dan daya pengeluaran yang rendah dalam kalangan petani padi menjadi punca kemiskinan.

Tanaman padi yang tidak dapat diusahakan menyebabkan kadar pengganguran dalam kalangan penduduk kampung meningkat. Bagi penduduk kampung, jumlah wang lima ratus ringgit yang diberikan oleh Syarikat Padu Menang Sdn. Bhd. amat bermakna buat mereka. Oleh kerana pertanian padi sawah tidak dapat diusahakan, rata-rata penduduk kampung menganggur. Fenomena tersebut dapat dikesan melalui petikan berikut:

\begin{abstract}
Beberapa orang bertepuk tangan. Yang paling kuat menepuk ialah Mat Dali dan Samad Betawi. Mereka kelihatan masih terlalu gembira menerima habuan wang sagu hati tadi. Lima ratus ringgit bagi mereka amat bermakna, apalagi setelah tanah sawah itu tidak dapat dikerjakan, lama mereka menganggur. Kalau ada kerja pun, tidak tetap. Pendapatan tidak seberapa. Justeru, wang ihsan itu ibarat tikaman loteri bagi mereka.
\end{abstract}

(Nenek, hlm: 127)

Kemiskinan juga menyebabkan penduduk kampung tidak mampu memiliki rumah. Seperti yang dinyatakan oleh Abraham Maslow (1970), manusia memerlukan keperluan fisiologi iaitu makanan, pakaian, tempat tinggal dan keperluan asas yang lain. Salah satu keperluan fisiologi yang dapat dikesan dalam novel ini ialah keperluan tempat tinggal. Oleh yang demikian, Mak Som telah mengemukakan cadangan semasa rundingan tersebut agar menyediakan rumah yang mampu dimiliki oleh penduduk kampung. Fenomena tersebut dapat dilihat melalui petikan di bawah:

"Kami menuntut supaya pemaju membina rumah yang mampu kami miliki. Beri peluang kepada kami orang miskin dan marhean memiliki rumah agar kami tidak terpinggir di bumi sendiri. Kami juga berhak memiliki rumah dalam proses pembangunan yang dirancang”, sambung Mak Som.

(Nenek, hlm: 132)

Sehubungan dengan itu, Norzalinda Mohd Ali Hanafiah (2006:119) mengatakan bahawa kemiskinan juga boleh membawa kepada homelessness. Ketidakmampuan memiliki rumah sendiri. Kemiskinan penduduk semakin meningkat kerana pengusaha dan pihak berwajib tidak memberi peluang pekerjaan kepada mereka. Sedangkan menurut Abraham Maslow (1970) jaminan keselamatan seperti kestabilan kerja penting kepada individu untuk mecapai tahap kesempurnaan kendiri. Dapat dikatakan bahawa Tok Nenggal tidak mampu mencapai kesempurnaan kendiri seperti yang disarankan oleh Abraham Maslow. Hal ini dapat dikesan melalui gambaran watak Tok Nenggal yang berusaha mencari kerja. Malang bagi Tok Nenggal alasan dia tidak mendapat pekerjaan adalah kerana faktor usia. Tok Nenggal juga tidak dapat meneruskan kemahiran bertukang kerana di zaman moden ini masyarakat sudah tidak berminat dengan rumah kayu. Fenomena tersebut dapat dibuktikan melalui petikan berikut:

Usaha Tok Nenggal untuk mendapat sebarang kerja yang bersesuaian di salah satu kilang di situ menghampakan. Tauke kilang menolak permohonan Tok Nenggal kerana usianya.Tok Nenggal tidak ada pilihan, kecuali menyandarkan harapannya kepada kemahiran bertukang. Namun, siapakah yang berminat membina rumah kayu lagi sekarang?

(Nenek, hlm: 228) 
Selain itu, Samad Betawi juga tidak dapat meneruskan perusahaan tempe dan keropoknya kerana faktor modal. Kemiskinan telah menghalang Samad Betawi untuk menyewa kilang dengan kadar sewa RM5,000 sebulan dan deposit sebanyak tiga bulan. Fenomena tersebut dapat dilihat melalui petikan di bawah:

Samad Betawi bercadang menyewa kilang kecil di situ untuk perusahaan tempe dan keropoknya. Dia tidak mampu kerana sewanya terlalu mahal. Ruang seluas 15 x40 kaki sewanya sehingga RM5,000 sebulan. Itu tidak termasuk syarat menyertakan deposit sebanyak tiga bulan.

(Nenek, hlm: 228)

Kemiskinan yang membelenggu penduduk Kampung Bertam ini disebabkan pembangunan yang tidak terancang.Pihak pemaju hanya ingin mengaut keuntungan tanpa memikirkan kesan jangka panjang kepada penduduk. Bermula dengan projek Perumahan Mega Jaya, penduduk kehilangan pekerjaan kerana tidak dapat mengusahakan tanaman padi. Sedangkan tanaman padi merupakan pekerjaan utama penduduk kampung. Tanah padi tersebut menjadi kering kontang. Seterusnya, apabila kawasan kontang tersebut diambil oleh kerajaan untuk dibangunkan sebagai kawasan perindustrian yang menjanjikan peluang pekerjaan kepada penduduk kampung tidak ditunaikan apabila pemaju dan pengusaha kilang memberi keutamaan kepada pekerja asing. Bukan itu sahaja, kadar sewa kedai yang dikenakan terlalu mahal menyebabkan penduduk tidak mampu meneruskan perusahaan kecil-kecilan membuat tempe dan keropok. Kampung tersebut terus mambangun tetapi masyarakat berada dalam kedaifan dalam pelbagai aspek kehidupan. Hal ini dinyatakan oleh Tuan Pah Rokiah Syed Hussain dan Hamidi Ismail:

\begin{abstract}
' Kemiskinan merupakan salah satu isu penting yang perlu diberikan tumpuan utama dalam agenda pembangunan negara. Masalah kemiskinan yang membelenggu penduduk boleh menyebabkan kehidupan mereka terseret jauh ke lubuk kedaifan, kemunduran, ketidakseimbangan ekonomi, sosial, politik, taraf pendidikan, dan kesejahteraan hidup."
\end{abstract}

(Tuan Pah Rokiah Syed Hussain dan Hamidi Ismail, 2002: 41)

Oleh yang demikian dalam Rancangan Malaysia Ketiga (1976), menyatakan punca kemiskinan disebabkan oleh kurangnya peluang pekerjaan yang produktif seperti pekerjaaan yang berkaitan dengan pentadbiran dan pengurusan, jualan, iktisas, teknikal, pengeluaran dan sebagainya (Norazlinda Mohd Ali Hanafiah, 2006: 118).

Justeru itu, (Durkheim 1938: 141) ada mengatakan dalam mengenalpasti fakta sosial kita haruslah mencari punca dan akibat daripada kewujudan fakta sosial. Sehubungan dengan itu, fenomena kemiskinan dalam novel Nenek berpunca daripada pembangunan yang tidak terkawal dan akibatnya penduduk mengalami masalah kemisikinan yang dapat dibahagikan kepada beberapa elemen. Antaranya ialah kehilangan pekerjaan, tidak mampu memiliki rumah sendiri, persaingan pekerjaan dengan buruh asing, dan kadar pengeluaran padi yang rendah. Kesemua ini dapat dijelaskan melalui sebab dan akibat daripada pembangunan yang tidak terancang di Kampung Bertam Malim.

\title{
Pembangunan sosioekonomi masyarakat
}

Hasil penelitian terhadap novel Nenek, Razali Endun mendedahkan sikap golongan tertentu yang menggunakan pembangunan sebagai alasan untuk membolehkan sesuatu kemajuan dilaksanakan. Dalam hal ini, pembangunan seperti yang dinyatakan oleh Milner Andrew (1996) dalam (Arba'ie Sujud dan Nik Rafidah Nik Muhammad Affendi dan Asiah Abdul Rahman, 2011: 206) bukan sahaja melibatkan aspek fizikal tetapi juga spiritual. Pada hakikatnya, kita tidak dapat menggelakkan pembangunan memang memberikan kesan yang positif kepada rakyat tetapi terdapat juga kesan negatif yang tidak dapat dielakkan. Hal ini sebagaimana yang dinyatakan oleh Kemala (1995) dalam (Arba'ie Sujud dan Nik Rafidah Nik Muhammad Affendi dan Asiah Abdul Rahman, 2011: 206) bahawa atas nama pembangunan, manusia-manusia kerdil sering tertindas dan terhimpit antara celah-celah batu besar. Selain itu, atas alasan pembangunan, manusia telah hilang sifat kemanusiaan.

Pembangunan mempunyai pelbagai maksud dan dimensi. Biasanya, pembangunan merujuk kepada usaha mengubah masyarakat atau negara daripada keadaan mundur kepada maju. Perubahan yang dimaksudkan meliputi pelbagai aspek kehidupan manusia seperti ekonomi, politik, sosial, pendidikan, psikologi dan sebagainya. Selain itu, ia juga merujuk kepada aspek-aspek fizikal, aspek kebendaan dan 
bukan kebendaan. Secara keseluruhannya, pembangunan ekonomi negara yang seimbang menjadi matlamat dalam penggubalan dasar pembangunan ekonomi negara sejak kemerdekaan sehingga kini (Hasnah Hussin dan Mardiana Nordin, 2007: 268).

Pembangunan ekonomi orang Melayu merupakan isu yang hangat dibincangkan sejak daripada dahulu lagi. Dari segi ekonomi, orang Melayu amat mundur berbanding ekonomi kaum-kaum lain di Malaysia. Menurut perangkaan Jabatan Penerangan Malaysia, bancian ke atas penduduk pada tahun 1970, didapati 49.3 peratus daripada keluarga di Semenanjung Malaysia menerima pendapatan di bawah paras kemiskinan. Daripada jumlah tersebut sebanyak 86 peratus keluarga miskin tinggal di luar bandar dan selebihnya 14 peratus tinggal di bandar. Dengan ini jelas menunjukkan bahawa rata-rata penduduk luar bandar adalah dalam kategori miskin, khususnya orang Melayu (Ishak Saat, 2012: 236).

Hal ini berlaku kerana orang Melayu hanya bergantung kepada satu sumber sahaja. Mereka juga tidak mahu berusaha mencari alternatif lain apabila pekerjaan yang diusahakan mengalami masalah atau tidak berjaya. Mereka mudah bersyukur dengan apa yang ada. Fenomena pembangunanan ekonomi orang Melayu dapat dilihat melalui petikan di bawah:

Petani Melayu biasanya hanya mengharapkan kepada satu sumber tanpa berikhtiar mencari rezeki sampingan. Mereka mudah bersyukur dengan apa yang mereka nampak. Kalau segantang sudah mencukupi, tidak payah menjadikan seguni. Konsep ini tidak akan membangunkan ekonomi. Orang Melayu akan sentiasa terasa menumpang di negerinya sendir

(Nenek, hlm: 136)

Penduduk Bertam Malim tidak pernah menolak pembangunan. Mereka menentang kerana kezaliman di sebalik pembangunan tersebut. Harga pampasan yang diberikan terlalu murah dan sehingga mereka tidak dapat memiliki rumah yang akan dibangunkan di kawasan tersebut. Fenomena tersebut dapat dilihat melalui petikan berikut:

\begin{abstract}
"Tuan-tuan yang salah faham", kata Mak Som, 'kami bukan membantah pembangunan, malah kami bersyukur jika kampung kami dimajukan. Yang kami bantah ialah kezaliman di sebalik projek pembangunan. Pihak pemaju dan kerajaan mesti peka dengan kepentingan orang kampung. Sudahlah harga ditawarkan terlalu rendah, tiada jaminan orang kampung diberi peluang memiliki hartanah di bandar baharu itu nanti. Ikuta apa yang saya faham,harga hartanah itu nanti bukannya murah. Kami yang kebanyakannya pesara, pekerja kampung, bagaimana kami mahu menikmati pembangunan itu bersama? Akhirnya, apa yang saya nampak nanti, orang kampung hilang tanah.Hak milik tanah berpindah ke tangan orang lain.Orang kampung hanya mampu berputih mata. Itukah yang dinamakan pembangunan?"
\end{abstract}

(Nenek, hlm: 131)

Dalam novel ini, Razali Endun mengungkapkan tentangan penduduk terhadap pengambilan tanah di kampung mereka. Berhubung dengan rancangan pembangunan di kawasan tersebut yang akan di majukan sebagai kawasan perindustrian tanpa dibincangkan secara telus dengan penduduk Kampung Bertam Malim. Hal inilah yang diketengahkan oleh Razali Endun seperti dalam petikan berikut:

"Taklimat malam ini memberi gambaran seolah-olah kita sebagai pemilik tanah sudah bersetuju
sepenuhnya dengan cadangan syarikat pemaju. Yang saya tahu, belum pun ada persetujuan, apalagi
pertemuan. Inilah pertemuan pertama sepanjang ingatan saya", kata Haji Khamis lagi. Dia puas hati
kerana ucapannya didengar dan tiada sesiapa memotong kata-katanya.

(Nenek, hlm: 129)

Berdasarkan penelitian pengkaji, Nenek mengungkapkan fenomena pembangunan ekonomi penduduk kampung setelah kawasan tersebut dibangunkan sebagai kawasan industri. Pembangunan tersebut telah memberi kesan yang negatif kepada penduduk kampung.Kawasan hutan gelam tersebut yang pada asalnya menjadi habitat flora dan fauna telah bertukar wajah dan dibangunkan sebagai kawasan perindustrian. Kawasan tersebut menjanjikan peluang pekerjaan kepada orang ramai, tetapi malangnya rakyat tempatan tidak dapat menikmati pembangunan di kampung mereka apabila pihak pengilang membawa masuk warga asing untuk dijadikan sebagai pekerja. Nasib penduduk tempatan begitu malang kerana pihak pengilang lebih memberi keutamaan kepada warga asing. Hal ini kerana pengilang boleh 
membayar upah yang murah dan menguntungkan pihak mereka. Dari sudut yang lain pula, nasib penduduk kampung Bertam Malim seakan-akan tidak terbela. Kawasan kampung mereka dibangunkan sebagai kawasan perindustrian yang menjanjikan peluang pekerjaan tetapi mereka tidak boleh menikmati peluang tersebut. Mereka diibaratkan seperti merempat di tanah air sendiri. Fenomena tersebut dapat dibuktikan melalui petikan berikut:

Di atas tanah hutan gelam itulah sekarang didirikan berpuluh-puluh kilang. Ada pelbagai kilang dibina di situ, daripada berstatus kecil,sederhana hingga ke taraf gudang besar. Perusahaan di situ memang menjana ekonomi dan memberi pekerjaan kepada orang ramai. Sayangnya, yang ramai bekerja di situ bukan orang tempatan tetapi rakyat asing yang dibawa masuk baik secara sah mahupun secara haram. Jumlah mereka meningkat setiap bulan kerana banyaknya pengilang yang memerlukan tenaga kerja murah.

(Nenek, hlm: 228)

Fenomena ini dipersetujui oleh Pakar ekonomi Pusat Pengajian Ekonomi, Kewangan dan Perbankan, Universiti Utara Malaysia, Prof Datuk Dr Amir Hussin Baharuddin dalam Sinar Online 10 Mac 2015 berkata, tidak dinafikan banyak sektor seperti industri binaan, perladangan dan perkhidmatan berkemungkinan lumpuh sekiranya Malaysia tidak mempunyai tenaga buruh murah. Natijahnya, kata beliau jumlah pekerja asing yang ada di Malaysia ketika ini, meskipun yang masuk secara sah, terlampau tinggi. Kita tidak perlu sebegitu ramai bukan semua sektor kita perlukan mereka bekerja perlunya ada undang-undang menghadkan bidang pekerjaan yang boleh diceburi mereka seperti bidang pertanian dan binaan. Masalahnya sektor korporat sibuk hendak menjimatkan kos, maka digajinya pekerja asing kerana bagi orang tempatan, gaji minimum RM900 itu tidak mencukupi.

Seiring dengan dimensi teori fakta sosial yang telah dikemukakan oleh Durkheim (1938: 142) bahawa fakta sosial tidak bersifat individualistik. Pada hakikatnya sosiologi menolak teori-teori yang tidak mempunyai nilai ilmiah, oleh kerana tujuannya adalah untuk mengubah organisasi sosial dan bukan untuk menafsirkannya. Oleh yang demikian, sesuatu masalah tidak boleh dianggap sebagai fakta sosial sekiranya masalah tersebut hanya berlaku ke atas individu sahaja. Ia mestilah dialami oleh masyarakat. Oleh yang demikian, pembangunan di kawasan tersebut memberi impak yang negatif kepada penduduk dan semua penduduk di kampung tersebut menghadapi masalah apabila pembangunan di kampung mereka dijalankan tanpa perancangan yang bijak.

\section{KESIMPULAN}

Rumusan daripada kajian ini menunjukkan bahawa terdapat empat fenomena sosial yang dominan dalam novel Nenek. Antaranya ialah tatacara perhubungan dalam masyarakat, kekeluargaan, kemiskinan dan pembangunan sosioekonomi masyarakat. Tatacara perhubungan dalam masyarakat dapat dijelaskan melalui adab berjiran, adab melayan tetamu dan budaya gotong-royong. Ketiga-tiga aspek ini masih lagi diamalkan dalam masyarakat. Seterusnya ialah fenomena kekeluargaan. Aspek kekeluargaan dapat dilihat melalui perhubungan yang positif antara ibu dan anak iaitu anak yang bertanggungjawab dan sikap anak yang menghormati ibu. Aspek kekeluargaan ini juga memperlihatkan hubungan positif suami isteri iaitu sikap suami yang bertanggungjawab dalam menguruskan rumahtangga. Manakala fenomena kemiskinan memberi gambaran kepada kita bahawa banyak faktor dan kesan dari masalah kemiskinan. Antaranya ialah daya pengeluaran padi yang rendah dalam kalangan petani, peningkatan kadar penggangguran, ketidakupayaan memiliki rumah, persaingan pekerjaan dengan buruh asing dan kadar sewa kedai yang tinggi menyebabkan kadar kemiskinan semakin meningkat. Fenomena pembangunan sosioekonomi masyarakat memperincikan ekonomi orang Melayu yang lebih mundur daripada kaum-kaum lain disebabkan oleh sikap mereka sendiri dan pembangunan yang mendatangkan banyak masalah kepada masyarakat. Oleh yang demikian, elemen fenomena sosial yang telah dijelaskan ini membuktikan bahawa novel Nenek tidak hanya memaparkan fenomena politik sahaja tetapi merangkumi pelbagai aspek dalam kehidupan masyarakat. Oleh yang demikian, novel Nenek telah memenuhi kriteria untuk diangkat sebagai pemenang dalam Hadiah Sastera Perdana Malaysia 2014. Teori fakta sosial yang dikemukakan oleh Emile Durkheim telah membantu pengkaji dalam menghuraikan mengenai fenomena sosial berdasarkan 
kepada tiga prinsip utama, iaitu bersifat objektif, bersifat sosiologi dan bersifat umum. Oleh itu, ketigaketiga prinsip yang dikemukakan ini dapat diaplikasikan dalam kajian.

\section{RUJUKAN}

Abraham, H Maslow. (1970). Motivation and personality. New York: Harper \& Row Publishers.

Abdul Halim Othman. (1993). Psikologi Melayu. Kuala Lumpur: Dewan Bahasa dan Pustaka, Kementerian Pendidikan Malaysia.

Abdullah Ghalib Ahmad Isa. (2003). Membina generasi berakhlak. Kuala Lumpur: Al-Hidayah Publishers.

Abd. Rahim Ab. Rashid. (2002). Wawasan dan agenda pendidikan. Kuala Lumpur: Utusan Publications Distributors Sdn. Bhd.

Arba'ie Sujud, Nik Rafidah Nik Muhammad Affendi dan Asiah Abdul Rahman. (2006). Sastera Melayu suatu pengantar. Kuala Lumpur: Tinta Press Sdn. Bhd.

Arba'ie Sujud, Liliy Salwani Razali dan Nik Rafidah Nik Muhammad Affendi. (2011). Fenomena sosial dalam cerita rakyat kanak-kanak. Jurnal PENDETA, 11 (2), 139-151.

Azemi Salim (terj). (1989). Antropologi sosial permulaan (Lucy Mair). Kuala Lumpur: Dewan Bahasa dan Pustaka.

Dewan Sastera. (2016). Nenek, novel sederhana yang besar. 45. Kuala Lumpur: Dewan Bahasa dan Pustaka.

Fatimah Abdullah. (2015). Keluarga dan permodenan di Malaysia. PTS Publications \& Distributions Sdn. Bhd.

Haron Din. (2007). Agama bisnes \& pengurusan. PTS Publications \& Distributions Sdn. Bhd.

Hasnah Hussin dan Mardiana Nordin. (2007). Pengajian Malaysia. Selangor: Oxford Fajar Sdn Bhd.

Hassan Shadily. (1984). Sosiologi untuk masyarakat Indonesia. Indonesia: PT.Bina Aksara.

Herni Syam. (2015). Fenomena sosial dalam kumpulan cerpen tasik syahdu karya A.Samad Said. (Latihan Ilmiah). Serdang, Universiti Putra Malaysia.

Hussin Salamon, Mohd. Nasir Ripin penterjemah. (1997). Marwan Ibrahim al-kaysi adab sopan dan Pekerti dalam Islam. Johor Universiti Teknologi Malaysia Skudai.

Ishak Saat. (2012). Politik dan masyarakat Melayu Perak. Universiti Tun Hussein Onn Malaysia.

Joseph S. Roucek, Roland L.Warren. (1984). Pengantar sosiologi. Indonesia: PT. Bina Aksara.

Johari Alias. (1997). Mencari kesempurnaan pekerti. Kuala Lumpur: Dewan Bahasa dan Pustaka.

Mustafa Haji Daud. (1999). Tamadun Islam. Utusan Publications \& Distibutors Sdn. Bhd.

Nik Rafidah Nik Muhammad Affendi. (2011). Novel remaja Jibam: kajian fenomena sosial. MANU Volume 17, $111-129$

Norita Hamdan. (1998). Novel salina karya A. Samad Said: dilihat dari sudut sosial. Serdang: Universiti Putra Malaysia.

Norazlinda Mohd Ali Hanafiah. (2006). Memahami kemiskinan dalam isu-isu pendidikan kerja sosial. Azlin Hilma Hillaluddin, Fatimah Zailly Ahmad Ramli, Rasimah Sayuti dan Yusmarhaini Yusof. Sintok: Universiti Utara Malaysia.

Norazit Selat. (1993). Konsep asas antropologi. Kuala Lumpur: Dewan Bahasa dan Pustaka.

Razali Endun. (2014). Nenek. Kuala Lumpur: Institut Terjemahan dan Buku Malaysia.

Rahimah Abdul Aziz. (1993). Idea-idea utama dalam sosiologi. Kuala Lumpur: Dewan Bahasa dan Pustaka.

Rogayah Ibrahim. (2000). Fenomena sosial dalam cerpen-cerpen Azizi Haji Abdullah. (Latihan Ilmiah). Serdang: Universiti Putra Malaysia.

Rohana Yusof. (1996). Asas sains sosial dari perspektif sosiologi. Kuala Lumpur: Dewan Bahasa dan Pustaka.

Rozumah Baharudin, Rumaya Juhari. (2002). Pengantar perkahwinan dan keluarga. Serdang: Universiti Putra Malaysia.

Shahnon Ahmad. (1989). Gubahan novel. Kuala Lumpur: Dewan Bahasa dan Pustaka.

Shamini A/P Paramasivam. (2015). Cerpen-cerpen karya Azizi Haji Abdullah dilihat daripada perspektif sosiologi. (Latihan Ilmiah). Serdang: Universiti Putra Malaysia.

S.Othman Kelantan. (1986). Teknik mengkaji novel (dalaman dan luaran). Kuala Lumpur: Karya Bistari. Sdn. Bhd.

The rules of sociological methods emile durkheim, (1938). Sarah A.Solovay dan John H. Mueller (Terj.) New York: The Free Press. $8^{\text {th }}$ Edition.

Tuan Pah Rokiah Syed Hussain, Hamidi Ismail. (2002). Kemiskinan di Malaysia: isu dan cabaran. Impak pembangunan kualiti hidup dan persekitaran Kuala Lumpur: Utusan Publications Distributors Sdn. Bhd.

Ting Chew Peh. (1997). Konsep asas sosiologi. Kuala Lumpur: Dewan Bahasa dan Pustaka.

Yahaya Ibrahim. (1995). Pembandaran dan kejiranan. Kuala Lumpur: Dewan Bahasa dan Pustaka.

Zamroni. (1992). Pengantar pengembangan teori sosial. Indonesia: PT.Bina Aksara.

Zulhilmi Paidi dan Rohani Ab. Ghani. (2003). Kenegaraan Malaysia isu-isu dalam pembinaan negara. Pahang: PTS Publications Distributors Sdn. Bhd.

Latifah Ariffin. (2016). Nenek cabar daya intelektual. Berita Harian Online. 10 Februari 2016. www.ukm.my/.../100216-BERITA_HARIAN-NENEK_CABAR_D. Diakses pada 31 Januari 2017. 